\title{
Peningkatan kapasitas kesadaran masyarakat terhadap mitigasi kerusakan pantai di Kelurahan Pelintung, Kecamatan Medang Kampai Kota Dumai-Riau
}

\author{
Rifardi *, Mubarak, \& Dessy Yoswaty \\ Jurusan Ilmu Kelautan, Fakultas Perikanan dan Kelautan, Universtas Riau \\ * rifardi@ lecturer.unri.ac.id
}

\begin{abstract}
Abstrak. Proses perubahan garis pantai berlangsung sampai saat ini di sepanjang pantai Kota Dumai dimana Kelurahan Pelintung merupakan salah satu kelurahan yang terletak sepanjang pantai ini terabrasi sebesar 1,33-16,84 meter/tahun. Kegiatan ini bertujuan meningkatkan kapasitas kesadaran masyarakat terhadap mitigasi kerusakan pantai melalui penyuluhan tentang pencegahan abrasi dan teknik implementasi jalur hijau sebagai penahan abrasi serta manfaat ekonomi dan ekologi jalur hijau. Metode yang digunakan adalah ceramah, diskusi, dan praktekdalam kelas dan lapangan, diikuti oleh 28 orang perwakilan masyarakat. Hasil kegiatan menunjukkan peningkatan signifikan pemahaman masyarakat tentang metoda sederhana mencegah kerusakan pantai yang berdampak positif terhadap ekologi (ketahanan pantai) dan ekonomi (alternatif income). Metoda penanaman mangrove pada pantai terabrasi akibat pengaruh arus dan gelombang dan pengolahan buah mangrove untuk menghasilkan sirup, wajik dan dodol mangrove (bakau). Hasil analisis ekonomi menunjukkan sirup pedada (1 botol @ Rp. 25.000) menghasilkan keuntungan Rp. 3.192.000/bulan, wajik pedada (1 bungkus Rp. 10.000) Rp. 1.476.000/bulan, dan dodol pedada (1 bungkus Rp. 15.000) Rp. 2.760.000/bulan. Mayoritas menyatakan mendukung dan antusias diadakannya kegiatan ini yaitu 49,7\% (Sangat Setuju), 37,8\% (Setuju), 11,80\% (Netral) dapat menerima serta mempraktekkan tentang peningkatan kesadaran masyarakat terhadap mitigasi kerusakan pantai dengan melakukan upaya penanaman mangrove dan diversifikasi produk olahan buah mangrove.
\end{abstract}

Kata kunci: abrasi, ketahanan pantai, mata pencaharian alternatif, mangrove, masyarakat

\begin{abstract}
Along the coast Keluruhan Pelintung has been an abrasion of 1.33-16.84 metres/year. This activity aims to increase the capacity of community awareness of coastal damage mitigation through counseling on abrasion prevention and green belt implementation techniques. The methods used were lectures, discussions, and classroom and field practice, followed by 28 community representatives. The results of the activity showed a significant increase in community's understanding of simple methods to prevent coastal damage which had a positive impact on ecology (coastal resilience) and the economy (alternative income). The method of planting mangroves on abrasive beaches is due to the influence of currents and waves and processing of mangrove fruit to produce syrup, diamonds and mangrove dodol (mangrove). The results of the economic analysis show that the pedada syrup (1 bottle @ Rp. 25,000) generates a profit of Rp. 3,192,000/month, wajik pedada (1 pack Rp. 10,000) Rp. 1,476,000/month, and dodol pedada (1 pack of Rp. 15,000) Rp. 2,760,000/month. The majority of the community stated that they supported and enthusiastically held this activity, namely 49.7\% (Strongly Agree), 37.8\% (Agree), 11.80\% (Neutral) could accept and practice increasing community awareness of mitigating coastal damage by making mangrove planting efforts and diversification of processed mangrove products.
\end{abstract}

Keywords: abrasion, coastal resilience, alternative livelihoods, mangroves, communities

To cite this article: Rifardi., Mubarak., \& D. Yoswaty. 2020. Peningkatan kapasitas kesadaran masyarakat terhadap mitigasi kerusakan pantai di Kelurahan Pelintung, Kecamatan Medang Kampai Kota Dumai-Riau. Unri Conference Series: Community Engagement 2: 16-23. https://doi.org/10.31258/unricsce.2.16-23

(C) 2020 Authors

Peer-review under responsibility of the organizing committee of Seminar Nasional Pemberdayaan Masyarakat 2020 


\section{PENDAHULUAN}

Upaya mitigasi terhadap kerusakan pantai yang disebabkan oleh proses abrasi hampir terjadi diseluruh daerah pantai, dimana proses yang terjadi pada daerah tersebut dapat disebabkan oleh faktor alam dan aktifitas antropogenis sekitarnya. Abrasi pantai adalah kerusakan garis pantai akibat dari terlepasnya material pantai, seperti pasir yang terus menerus dihantam oleh gelombang laut, atau dikarenakan oleh terjadinya perubahan keseimbangan angkutan sedimen di perairan pantai (Hang Tuah, dalam Fajri 2012). Garis pantai adalah salah satu fitur linear yang paling penting di permukaan bumi, yang menampilkan sifat dinamis dan merupakan indikator untuk erosi pantai dan akresi (Ghosh et al., 2015). Sebagai sebuah kawasan peralihan darat dan laut, pantai merupakan sebuah lingkungan yang unik dimana udara, air, dan bebatuan satu sama lainnya saling berhubungan (Kasim, 2012). Perkembangan teknologi yang cukup cepat membuat arah studi monitoring dan analisa perubahan garis pantai lebih banyak menggunakan citra satelit penginderaan jauh (Aryastana et al , 2016).

Perubahan garis pantai dapat terjadi karena faktor alami seperti pasang surut, kecepatan angin, dan sedimentasi, serta faktor manusia. Faktor manusia antara lain pembangunan pelabuhan dan fasilitasfasilitasnya, misalnya pemecah ombak, pertambangan, pengerukan, perusakan vegetasi pantai, pertambakan, serta reklamasi pantai (Geography Education, 2012). Selain itu, perubahan pantai terjadi apabila proses geomorfologi yang terjadi pada segmen pantai melebihi proses yang biasa terjadi. Perubahan proses geomorfologi merupakan akibat dari sejumlah parameter oseanografi yang berperan seperti gelombang, arus, dan pasang surut (Opa, 2011). Secara ekonomis pantai dapat memberikan pendapatan kepada Negara dan penduduk karena pantai sangat berpotensi sebagai daerah penghasil ikan, wisata, kegiatan industri, pemukirnan, pelabuhan, pertambangan, konservasi lahan dan lain-lain. Tetapi dengan adanya proses dan tenaga yang bersifat alami atau non alami maka pantai akan mengalami perubahan, salah satunya adalah adanya perubahan garis pantai (Lubis et al, 2017).

Proses diatas juga berlangsung sampai saat ini di sepanjang pantai Kota Dumai dimana Keluruahan Pelintung merupakan salah satu kelurahan yang terletak sepanjang pantai ini. Rifardi dan Isty (2017) menemukan bahwa garis pantai Kota Dumai telah mengalami perubahan karena abrasi dan sedimentasi, dan dominan pantai kota ini mengalami abrasi dengan kecepatan 1,33-16,84 meter/tahun. Perubahan garis pantai ini dipengaruhi oleh sistem arus yang mengalir menyapu pantai Kota Dumai dengan kecepatan 0,11-0,38 meter/detik mengalir dari selat Malaka. Sedimen litogeneous dibuang ke daerah pantai oleh sungai-sungai yang mengalir dari daerah pedalaman kota, dan terakumulasi di daerah tersebut sebanyak 7.220 ton / ha / tahun. Daerah ini ditandai dengan pasir halus sampai sedimen lendir kasar $(\mathrm{Mz}=2,27-4,44 \varnothing)$.

Faktor dominan yang menyebabkan perubahan garis pantai Kota Dumai adalah sistem arus yang mengalir dari Selat Malaka melalui daerah pasang surut, dan transportasi sedimen lithogeneous dari daratan. Isty dan Rifardi (2020) menemukan kondisi pasang surut dimana kecepatan arus maksimum terjadi pada saat pasang purnama yang mencapai $1,84 \mathrm{~m} / \mathrm{s}$.

Tipologi dan morpologi yang hampir sama dengan pantai Kota Dumai adalah Pulau Bengkalis khususnya semanjung bagian utara yaitu pada Desa Mekom, dan Pulau Rangsang Kabupaten Meranti Propinsi Riau. Rifardi et al (2018) melakukan penelitian perubahan garis pantai di Tanjung Bengkalis, Provinsi Riau, menemukan tingginya tingkat abrasi selama 20 tahun; 1995-2015 mencapai 38,02 meter/ tahun. Faktor utama penyebab perubahan garis pantai adalah karena sistem Selat Malaka. Lilian et al (2013) menemukan pesisir utara Pulau Rangsang mengalami abrasi tinggi selama periode 13 tahun (Tahun 2000-2013). Perubahan ratarata relatif garis pantai selama periode tersebut (kecepatan abrasi) 7,5 meter/tahun, dan kecepatan abrasi tertinggi ditemukan di Desa Kedabu Rapat sebesar 8,5 meter/tahun.

Proses abrasi sepanjang pantai Kota Dumai terjadi sejak beberapa dekade tahun lalu sampai sekarang diakibatkan oleh faktor alami dan manusia. Kurangnya pemahaman beberapa stakeholders tentang peranan jalur hijau (green belt) sepanjang pantai yang mampu mengendalikan kerusakan pantai dan sebagai salah satu bentuk upaya mitigasi proses abrasi, dan kurangnya pemahaman beberapa stakeholder tentang pengaruh arus dan gelombang terhadap ketahanan pantai, perlu dilakukan peningkatan kapasitas kesadaran masyarakat terhadap mitigasi kerusakan pantai baik akibat proses di Kelurahan Pelintung, Kecamatan Medang Kampai, Kota Dumai-Riau. Berdasarkan wawancara dan diskusi dengan pemuka masyarakat setempat kecepatan abrasi kelurahan ini berkisar 5 meter/tahun. Gambaran ini tidak jauh berbeda dengan hasil penelitian Rifardi dan Isty (2017) seperti yang dijelaskan diatas. Selain itu, sudah banyak penelitian dilakukan oleh para ahli terkait perubahan pantai sepanjang Rupat diantaranya Rifardi et al., (2015); Rifardi (2015); Syahminan at al., (2015); 
Merian at al., (2016); Rifardi et al., (2016); Putra et al., (2016); Rifardi \& Badrun (2017); Isty \& Rifardi (2020); Rifardi et al (2020)

Kegiatan pengabdian dalam bentuk penyuluhan kepada masyarakat bertujuan untuk 1). menjelaskan tentang pentingnya menjaga ekosistem pantai untuk menghindari terjadi proses abrasi, 2). memberikan pemahaman tentang abrasi dan sedimentasi serta konsekwensi terhadap kehidupan manusia dan keberlangsungan sumberdaya alam, dan 3). peningkatan kapasitas kesadaran masyarakat terhadap mitigasi kerusakan pantai di Kelurahan Pelintung, Kecamatan Medang Kampai, Kota Dumai-Riau.

Khalayak sasaran sasaran yang terlibat dalam kegiatan pengabdian ini adalah kelompok masyarakat di Kelurahan Pelintung terdiri dari elompok nelayan, petani dan ibu PKK/rumah tangga yang ingin melestarikan hutan mangrove dan berwirausaha dengan mengolah buah mangrove untuk meningkatkan pendapatan keluarga. Belum adanya upaya penanaman bakau dan usaha pengolahan buah mangrove pedada (Sonneratia caseolaris) berupa sirup, wajik dan dodol di Kelurahan Pelintung dijadikan dasar untuk memberikan pengetahuan dan menumbuhkan jiwa kewirausahaan kepada masyarakat.

Dengan mengikuti kegiatan pengabdian terintegrasi ini, masyarakat dapat dilibatkan dalam upaya konservasi hutan mangrove dan diversifikasi produk olahan buah mangrove. Hal ini tentu akan meningkatan kapasitas kesadaran masyarakat terhadap mitigasi kerusakan pantai sekaligus menumbuhkan jiwa kewirausahaan masyarakat di Kelurahan Pelintung, Kecamatan Medang Kampai, Kota Dumai-Riau.

Kelompok masyarakat (Pokmas) di Kelurahan Pelintung adalah sebagai mitra konservasi hutan mangrove sebanyak 20 orang yang bermata pencaharian sebagai nelayan, petani dan pegawai kantor Kelurahan Pelintung. Pokmas ini dibagi atas 4 kelompok, dimana 1 kelompok terdiri atas 5 orang. Pokmas Konservasi Mangrove dibentuk untuk melakukan penanaman bibit mangrove sebanyak 400 bibit sebagai upaya untuk mencegah kerusakan pantai. Kelompok ibu PKK/rumah tangga di Kelurahan Pelintung adalah sebagai mitra pengolahan buah mangrove sebanyak 8 orang, diberi buah mangrove pedada (S. caseolaris) sebanyak $3 \mathrm{~kg}$ yang berkualitas baik untuk 3 kelompok, dilakukan pengolahan sirup, wajik dan dodol buah mangrove.

\section{METODE PENERAPAN}

Metode yang digunakan dalam pelaksanaan kegiatan pengabdian adalah ceramah, diskusi dan praktek lapang. Metode ceramah, digunakan untuk menguraikan materi yang berkaitan dengan abrasi dan sedimentasi di dalam ruangan. Metode diskusi, digunakan untuk umpan balik berkaitan dengan ceramah dan kalau ada masalah (dilakukan diruangan atau dilapangan). Salah satu materi penting dalam mitigasi kerusakan pantai dengan menjelaskan peranan ekosistem hutan mangrove atau bakau.

Metoda penentuan tingkat ketercapaian kegiatan ini dilakukan dengan cara memberikan pre test, post test dan praktek lapangan kepada seluruh peserta sebanyak 28 (dua puluh delapan) orang terdiri dari Lurah, Babinsa Kamtibmas, RW, RT dan Karang Taruna serta tokoh pemuda dan ibu ibu. Setelah ceramah dan diskusi selesai, selanjutnya dilaksanakan praktek penanaman mangrove pada pantai terabrasi akibat pengaruh arus dan gelombang dilakukan dengan cara 3 batang pohon mangrove ditanam pada satu lobang dan ditopang oleh bambu berukuran panjang $40 \mathrm{~cm}$. Sedangkan pengolahan buah mangrove untuk menghasilkan sirup dan dodol mangrove (bakau) dilaksanakan didalam ruangan.

Alat ukur sederhana dan cepat untuk mengevaluasi ketercapaian peningkatan kapasitas kesadaran Masyarakat terhadap Mitigasi Kerusakan Pantai di Kelurahan Pelintung, Kecamatan Medang Kampai, Kota Dumai-Riau adalah hasil test yang dilakukan sebelum dan setelah kegiatan penyuluhan. Hasil ini dapat menggambarkan: 1). Perubahan pola pikir masyarakat tentang tanggungjawab pemeliharaan lingkungan khususnya lingkungan wilayah pesisir dan pantai, 2). Pemahaman dan kesadaran masyarakat tentang pentingnya mencegah kerusakan pantai akibat abrasi yang disebabkan oleh faktor alam dan manusia, 3). Meningkatnya ketrampilan masyarakat melalui teknologi sederhana cara melakukan mitigasi kerusakan pantai akibat abrasi yaitu teknik penanam pohon bakau, 4).Menambah ketrampilan dan solusi mata pencaharian alternatif masyarakat melalui teknologi sederhana cara memanfaatkan bauh bakau untuk dioleh menjadi produk turunan berupa sirup dan dodol buah bakau (mangrove). 


\section{HASIL DAN KETERCAPAIAN SASARAN}

\section{Gambaran Umum Masyarakat Sasaran}

Peningkatan kesadaran masyarakat terhadap mitigasi kerusakan pantai di Kelurahan Pelintung yaitu melalui upaya konservasi hutan mangrove. Salah satu cara adalah dengan penanaman bibit mangrove. Pada kegiatan ini tim penyuluh telah menyediakan 400 bibit mangrove dari jenis Rhizophora apiculata, Sonneratia caseolaris dan Avicennia marina, termasuk membentuk kelompok masyarakat (POKMAS) sadar lingkungan. Selain itu, dilakukan juga penglibatan ibu PKK/rumah tangga untuk membuat olahan buah mangrove pedada (Sonneratia caseolaris).

Masyarakat di Kelurahan Pelintung berpartisipasi dalam melakukan pelestarian hutan mangrove. Kelurahan Pelintung dipilih karena kepentingan penyertaan masyarakat untuk meningkatkan pengetahuan, pemahaman dan kesadaran tentang mitigasi kerusakan pantai melalui penanaman mangrove dan pengolahan buah mangrove berupa sirup, wajik dan dodol. Kelurahan Pelintung merupakan salah satu desa yang diharapkan bisa menjadi daerah percontohan dalam konservasi hutan mangrove dan diversifikasi produk olahan buah mangrove. Masyarakat sasaran dari POKMAS dan ibu PKK/rumah tangga ini berasal dari beberapa latar belakang pekerjaan seperti dapat dilihat pada Tabel 1 .

Tabel 1. Peserta penyuluhan mitigasi kerusakan pantai di Kelurahan Pelintung.

\begin{tabular}{clll}
\hline No. & \multicolumn{1}{c}{ Nama } & Umur (Tahun) & Pekerjaan \\
\hline \multicolumn{2}{c}{ Pokmas penanaman bibit mangrove: } & & \\
\hline 1 & Al Azni, ST & 54 & Lurah Pelintung \\
2 & Taufik Akbar & 45 & Karta \\
3 & Edi Suryanto & 38 & Bhubin Kamdibmas \\
4 & Darmawi & 57 & Anggota LPMK \\
5 & Jamil & 29 & Anggota LPMK \\
6 & Gustami & 36 & Petani \\
7 & Jailani & 42 & Petani \\
8 & Sugiri & 37 & Petani \\
9 & Nasrun & 41 & Petani \\
10 & Abdul Aziz & 47 & Petani \\
11 & Syahrun & 35 & Anggota LPMK \\
12 & Nur Ardoh & 27 & Kader KPKB \\
13 & Bahron & 33 & Seksi Keamanan LPMK \\
14 & Faizal Ahmad & 34 & Nelayan \\
15 & Arief Budiman & 43 & Nelayan \\
16 & Khairun Nuzam & 45 & Nelayan \\
17 & Rio Syafrianda & 31 & Nelayan \\
18 & Taufiq Akbar & 51 & Karta \\
19 & Hendri & 30 & Anggota UMK \\
20 & Yusmar Efendi & 50 & Anggota UMK \\
\hline Kelompok pengolahan buah mangrove: & & \\
\hline 21 & Siti Yulaika & 34 & Anggota LPMK \\
22 & Desi & 46 & Kader KPKB \\
23 & Ifo Maya Sari & 40 & Anggota PPKBD \\
24 & Toyibah & 27 & TKS Kantor Kelurahan Pelintung \\
25 & Armaini & 42 & Pegawai Kantor Kelurahan Pelintung \\
26 & Busamah & 38 & Ibu rumah tangga \\
27 & Fauziah & 45 & Kader KPKB \\
28 & Purwaningsih & 32 & Kader KPKB \\
\hline & & & \\
\hline
\end{tabular}

Berdasarkan data peserta penyuluhan tidak sulit untuk menerima pengetahuan, pemahaman dan demostrasi yang telah diberikan oleh tim penyuluh LPPM Unri, dimana peserta turut berperan aktif dalam berusaha untuk melestarikan lingkungan pantai dan meningkatkan kesejahteraan keluarga. Kelompok masyarakat (POKMAS) 
dan ibu PKK/rumahtangga telah memperoleh pengetahuan tentang penerapan iptek berupa konservasi hutan mangrove dan penganekaragaman produk olahan buah mangrove. Hal ini mendukung peran serta masyarakat dalam meningkatkan kesadaran pentingnya mitigasi kerusakan pantai (Gambar 1) dan menumbuhkan jiwa kewirausahaan melalui produk olahan buah mangrove (gambar 2) dapat dijual di lokasi wisata Kelurahan Pelintung.
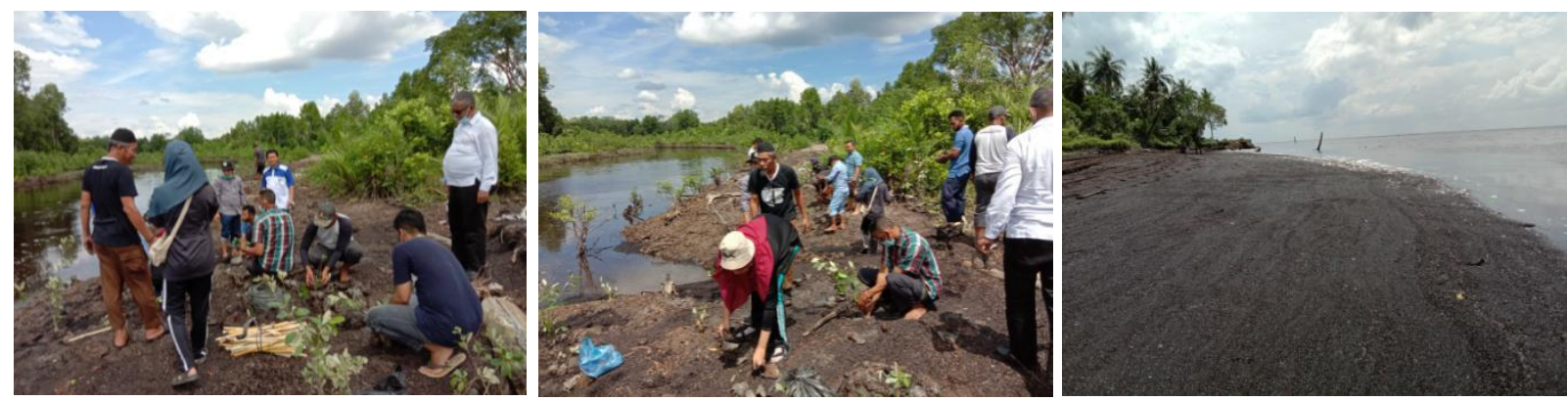

Gambar 1. Aktivitas Pokmas penanaman mangrove sebagai upaya mitigasi kerusakan pantai
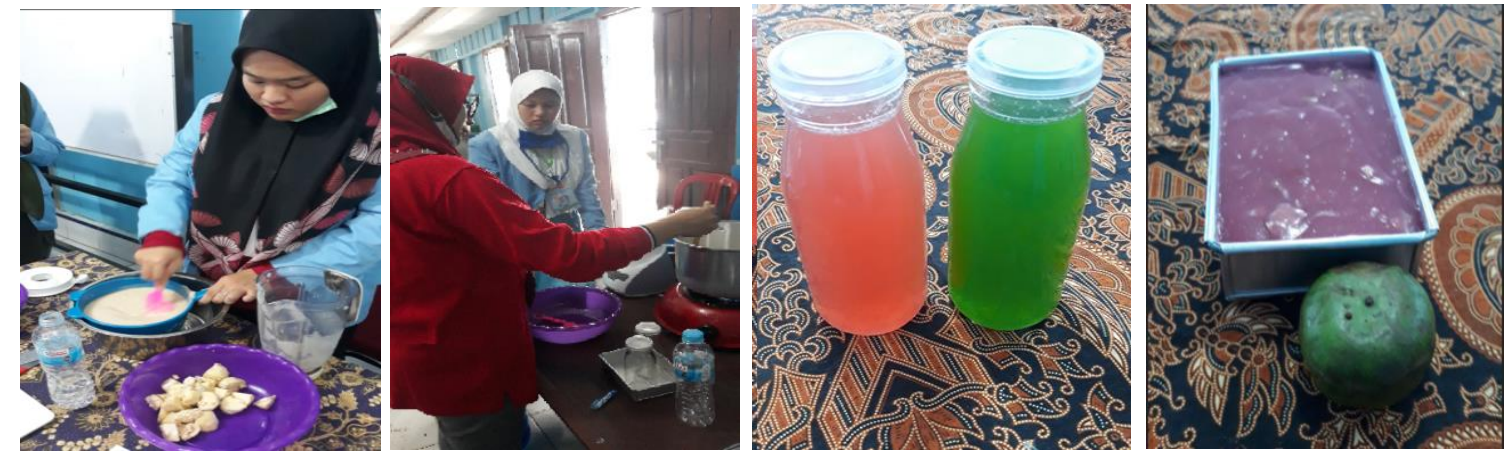

Gambar 2. Aktivitas kewirausahaan ibu ibu PKK melalui produk olahan buah mangrove

\section{Tingkat Ketercapaian Sasaran Program}

Kegiatan tahap selanjutnya adalah memonitor dan mengevaluasi kegiatan pengabdian melalui persepsi peserta penyuluhan (penyebaran kuestioner). Pengendalian kegiatan pengabdian meliputi pemantauan, evaluasi, pelaporan dan pengawasan, yang diarahkan untuk pengendalian perencanaan dan pelaksanaan kegiatan.

Hasil evaluasi menunjukkan mayoritas dari responden (berjumlah 28 orang peserta) menyatakan mendukung dan antusias dengan diadakannya kegiatan pengabdian ini dengan rencian: 49,7\% (Sangat Setuju), $37,8 \%$ (Setuju), 11,80\% (Netral) dapat menerima serta mempraktekkan tentang peningkatan kesadaran masyarakat terhadap mitigasi kerusakan pantai yaitu dengan melakukan upaya penanaman bibit mangrove dan diversifikasi produk olahan buah mangrove pedada (Sonneratia caseolaris). Persepsi responden sebanyak 0,7\% (tidak setuju) menyatakan bahwa pelaksanaan kegiatan ini masih kurang memadai sarana dan prasarananya. Kegiatan pengolahan buah mangrove masih dalam skala rumah tangga (home industry).

Peserta pelatihan dapat mengembangkan upaya pelestarian hutan mangrove dan diversifikasi olahan buah mangrove dengan membentuk kelompok masyarakat (POKMAS). Hal ini karena peserta juga diberi informasi oleh tim penyuluh untuk melakukan promosi upaya konservasi hutan mangrove dan memasarkan produk olahan buah mangrove secara konfensional (offline) dan online melalui akun sosial media seperti email, instagram dan facebook. Diharapkan akan semakin meningkatkan kesadaran masyarakat dalam mitigasi kerusakan pantai Legenda di Kelurahan Pelintung.

Peserta yang mempunyai motivasi untuk melakukan penanaman bibit mangrove dan mangrove tersebut dapat dijual untuk menambah pendapatan masyarakat. Hasil produk olahan buah mangrove (sirup, wajik dan dodol) yang telah dibuat oleh peserta juga dapat dipasarkan sehingga turut meningkatkan pendapatan dan alternatif mata pencaharian bagi peserta. Produk olahan buah mangrove untuk memudahkan pemasaran dapat diberi label nama yang menggambarkan produksi dari masyarakat seperti sirup, wajik dan dodol khas 
Kelurahan Pelintung. Soetomo (2015) mengungkapkan bahwa pemberdayaan masyarakat sebagai pendekatan untuk berbagai kebijakan pembangunan masyarakat. Secara sederhana, pembangunan diarahkan berpusat pada masyarakat secara langsung.

Produksi olahan buah mangrove tersebut dapat memberikan keuntungan ekonomi bagi masyarakat sebagai mata pencaharian alternatif. Hasil analisis ekonomi menunjukkan sirup pedada (1 botol @ Rp. 25.000) menghasilkan keuntungan Rp. 3.192.000/bulan, wajik pedada (1 bungkus Rp. 10.000) keuntungan Rp. 1.476.000/bulan, dan dodol pedada (1 bungkus Rp. 15.000) keuntungan Rp. 2.760.000/bulan.

Pohon mangrove pedada (S. caseolaris) mempunyai daya adaptasi yang luas dan toleransi yang tinggi terhadap berbagai kondisi lingkungan. Ada dua jenis buah pedada yang dapat diolah yaitu Sonneratia caseolaris dan Sonneratia alba (Kesemat, 2012). Sifat buah mangrove pedada tidak beracun, asam dan dapat langsung dimakan. Regenerasi alami buah mangrove pedada cukup sulit, tetapi dapat dipermudah dengan regenerasi buatan melalui pengadaan bibit pedada (Santoso et al 2005). Nilai keunggulan dari sirup pedada berdasarkan penelitian Raindly (2006) adalah kandungan vitamin C cukup tinggi (50,1 mg/100 gr sirup), dan mengandung iodium dengan kadar $0,68 \mathrm{mg} / \mathrm{kg}$ sirup. Hal ini memenuhi syarat mutu sirup sesuai dengan SNI 01-3544- 1994 sehingga aman dikonsumsi dan diproduksi secara berkelanjutan. Sirup buah pedada dapat dijadikan sebagai prospek untuk membentuk wirausaha dan diharapkan dapat memberikan nilai tambah bagi mangrove baik dari sisi ekologi maupun ekonomi.

Menurut Manalu (2011), buah mangrove pedada mengandung kadar air (bb) 84,76\%, kadar abu (bk) 8,40\%, kadar lemak(bk) 4,82\%, kadar protein (bk) 9,21\%, dan kadar karbohidrat (bk) 77,57\% . Buah pedada banyak mengandung vitamin seperti vitamin A, B1, B2, dan C. Kadar vitamin A, B1, B2, dan C berturut turut adalah 221,97 IU/100 gram, 5,04 mg/100 gram, 7,65 mg/100 gram, dan 56,74 mg/100 gram.

Kulit buah pedada mengandung tanin yang berfungsi sebagai antioksidan karena kemampuannya dalam menstabilkan fraksi lipida dan keaktifannya dalam penghambatan lipoksigenase. Tanin merupakan salah satu senyawa fenol kompleks. Bagian daging buah pedada mengandung saponin dan steroid yang memiliki aktivitas sebagai analgesik dan anti inflamasi (Bandarayanake, 2002). Ekstrak buah pedada secara tradisional sudah digunakan sebagai antiseptik, mengobati keseleo, dan mencegah pendarahan (Minqing et al., 2009).

Makanan tradisional berupa sirup, wajik dan dodol dari buah mangrove pedada (S. caseolaris) yang telah diolah, maka tidak memiliki rasa yang pahit. Penanganan sirup, wajik dan dodol pedada diharapkan dapat diterima oleh masyarakat dan sebagai alternatif usaha untuk meningkatkan kesejahteraan masyarakat. Menurut Subekti (2012), proses pengolahan buah pedada dapat dilakukan dalam skala rumah tangga dan skala industri kecil.

\section{KESIMPULAN}

Hasil kegiatan penyuluhan menunjukkan peningkatan signifikan pemahaman masyarakat tentang metoda sederhana untuk mitigasi kerusakan pantai. Metoda ini memiliki multi dampak diantaranya berdampak positif terhadap ekologi (ketahanan pantai) dan ekonomi (alternatif income). Hal ini tergambar dari hasil pra test dan post test yang diberikan kepada peserta penyuluhan. Metoda penanaman mangrove pada pantai terabrasi akibat pengaruh arus dan gelombang dilakukan dengan cara 3 batang pohon mangrove ditanam pada satu lobang dan ditopang oleh bambu berukuran panjang $40 \mathrm{~cm}$. Selanjutnya metoda pengolahan buah mangrove untuk menghasilkan sirup, wajik dan dodol mangrove (bakau).

Mayoritas dari responden (berjumlah 28 orang peserta) menyatakan mendukung dan antusias dengan diadakannya kegiatan dengan rincian 49,7\% (Sangat Setuju), 37,8\% (Setuju),11,80 \% (Netral) dapat menerima serta mempraktekkan tentang peningkatan kesadaran masyarakat terhadap mitigasi kerusakan pantai yaitu dengan melakukan upaya pembibitan mangrove dan diversifikasi produk olahan buah mangrove pedada. Persepsi responden sebanyak 0,7\% (tidak setuju) menyatakan bahwa pelaksanaan kegiatan ini masih kurang memadai sarana dan prasarananya. Kegiatan pengolahan buah mangrove masih dalam skala rumah tangga (home industry).

Berdasarkan antusias, respon dan hasil kegiatan penyuluhan direkomendasikan huntuk melakukan pembinaan lanjutan terhadap peserta pelatihan karena dapat mengembangkan upaya pelestarian hutan mangrove dan diversifikasi olahan buah mangrove terutama terhadap kelompok masyarakat (POKMAS) yang sudah dibentuk untuk menambah pendapatan masyarakat. 


\section{UCAPAN TERIMA KASIH}

Kami mengucapkan terima kasih yang sebesar-besarnya kepada Lembaga Penelitian dan Pengabdian Kepada Masyarakat Riset Universitas Riau yang telah mendanai kegiatan pengabdian kepada masyarakat berdasarkan nomor kontrak: 887/UN.19.5.1.3 /PT.01.03/2020. Ucapan terimakasih disampaikan juga kepada seluruh masyarakat dan perangkat Keluruhan Pelintung, Kecamatan Medang Kampai, Kota Dumai atas partisipasi dan dukungan penuh terlaksananya kegiatan pengabdian ini.

\section{DAFTAR PUSTAKA}

Aryastana, P., I. G. A. P. Eryani dan K. W. Candrayana. 2016. Perubahan garis pantai dengan citra satelit di Kabupaten Gianyar. Paduraksa, 5(2), 70-81.

Bandarayanake. 2002. Bioactivities, bioactive compounds and chemical constituents of mangrove plants. Kluwer Academic Publishers. Ecology of mangrove plant, 10(2), 421-452.

Ferli, F., Rifardi., dan A. Tanjung. 2012. Studi Abrasi Pantai Kota Padang, Provinsi Sumatera Barat. Jurnal Perikanan dan Kelautan, 17(2), 36-42.

Geographi, E. 2012. Perubahan Garis Pantai di Muara Sungai. Pekanbaru. http://tulisanachie.blogspot.com. Diakses pada 28 Mei 2015.

Ghosh, M.K., L. Kumar, and C. Roy. 2015. Monitoring the coastline change of Hatiya Island in Bangladesh using remote sensing techniques. ISPRS Journal of Photogrammetry and Remote Sensing, 101, 137-144

Isty, H. T. and Rifardi. 2020. Current pattern causes the formation of small islands in the Rupat Strait, Riau Province, Indonesia. ASM Science Journal (In review).

Kasim, F. 2012. Pendekatan Beberapa Metode dalam Monitoring Perubahan Garis Pantai Menggunakan Dataset Penginderaan Jauh Landsat dan SIG. Jurnal Ilmiah Agropolitan, 5(1), 620-635.

Kesemat. 2012. Beragam produk olahan berbahan dasar mangrove. http://www. Mangroveforthefuture.org. Diakses tanggal 20 Juni 2020.

Lilian, A., Mubarak dan Rifardi. 2013. Analisis Sedimen dan Perubahan Garis Pantai Utara Pulau Rangsang Kabupaten Kepulauan Meranti. Respository.unri.ac.id

Lubis, D. P., M. Pinem, M. A. N, Simanjuntak. 2017. Analisis perubahan garis pantai dengan menggunakan citra penginderaan jauh (studi kasus di kecamatan talawi kabupaten batubara). Geografi, 9(1), 21-31.

Manalu, R. D. 2011. Kadar beberapa vitamin pada buah pedada (Sonneratia caseolaris) dan hasil olahannya. Skripsi. Departemen Teknologi Hasil Perairan. Fakultas Perikanan dan Ilmu Kelautan.Institut Pertanian Bogor.

Merian, R. D., Mubarak dan S. Sutikno. 2016. Analisis kualitas perairan muara Sungai Dumai ditinjau dari sspek fisika, kimia dan biologi. Dinamika Lingkungan Indonesia, 3 (2), 107-112.

Minqing T., D. Haofu., L. Xiaoming and W. Bingui. 2009. Chemical constituents of marine medicinal mangrove plant Sonneratia caseolaris, Chenese. Journal of Oceanology and Limnology, 27(2), 288-296.

Opa, E.T. 2011. Perubahan garis pantai Desa Bentenan Kecamatan Pusomaen, Minahasa Tenggara. Jurnal Perikanan dan Kelautan Tropis, 3.

Putra K., R., Rifardi dan Elizal. 2016. Kapasitas Asimilasi Total Suspended Solid (TSS) di Muara Sungai Nerbit Besar Kelurahan Lubuk Gaung Kecamatan Sungai Sembilan Kota Dumai Provinsi Riau. Terubuk, 4(1), 90-103.

Raindly. 2006. Sirup apel mangrove. Penerbit Pustaka Pelajar. Yogyakarta.

Rifardi., Syahminan., R. B. and N. Fidiatur. 2015. Sedimentary Environments of the Dumai Coastal Waters on the East Coast of Central Sumatera Island, Indonesia. ASM Sci. J. 9(2), 9-16.

Rifardi 2015, Studi karakteristik sedimen estuaria Sungai Dumai dan estuaria Sungai Mesjid Selat Rupat, 71 p. Lembaga Penelitian dan Pengabdian Kepada Masyarakat, Universitas Riau, Pekanbaru.

Rifardi., Syahrul. K. Romel and P. Indrawan 2016. Supplai sedimen lithogeneous ke perairan Selat Rupat. 44 p. Lembaga Penelitian dan Pengabdian Kepada Masyarakat, Universitas Riau, Pekanbaru.

Rifardi and Y. Badrun. 2017. Sandbar Formation in the Mesjid River Estuary, Rupat Strait, Riau Province, Indonesia. Indonesia Journal of Geography, 49(1), 65-75. 
Rifardi and Hafiza T.I. 2017. Preliminary Report on the Study of the Shoreline Changes of Dumai City Facing the Strait of Rupat, Indonesia. Abtract of the 6th International Seminar on Fiheries and Marine Science, Pekanbaru, September 23, 2017.

Rifardi, R. Chairunisa and Elizal. 2018. The Study of the shoreline change of Bengkalis Cape, Indonesia. ASM Science Journal, 11 (1): 23-31.

Rifardi., H. T. Isty and R. A. Wati. 2020. Geomorphologycal dynamic of the Strait of Rupat on the East Coast of Central Sumatera Island Indonesia. ASM Science Journal, (In review).

Santoso, N., B. C. Nurcahya., A. F. Siregar dan I. Farida. 2005. Resep Makanan Berbahan Baku Mangrove dan Pemanfaatan Nipah. Jakarta. Lembaga Pengkajian dan Pengembangan Mangrove.

Soetomo. 2015. Pemberdayaan masyarakat. Penerbit Pustaka Pelajar, Yogyakarta.

Subekti, S. 2012. Pengelolaan mangrove sebagai salah satu keanekaragaman bahan pangan. Prosiding SNST ke-3. Jurusan Teknik Lingkungan Fakultas Teknik Universitas Pandanaran, Semarang.

Syahminan., E. Riani., S. Anwar and Rifardi. 2015. Heavy metals pollution status Pb and Cd in sediments in Dumai Sea western waters-Riau Province. Pengelolaan Sumberdaya Alam dan Lingkungan, 5(2), 133-140, DOI: 10.19081/jpsl.5.2.133 